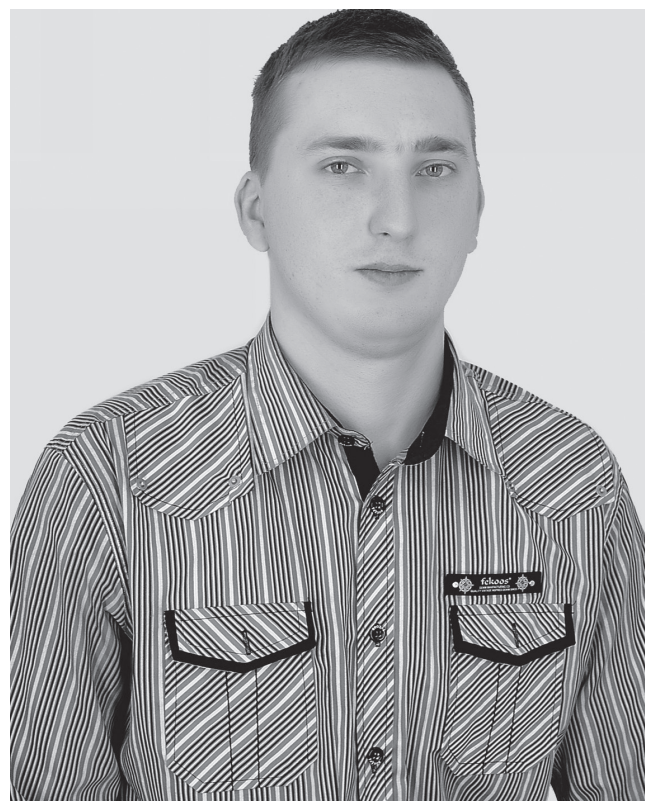

UDC 330.341.1:159.9

Omelyanenko Vitalii Anatoliyozych, PhD, Senior Lecturer of Business Economics and Administration Department, Sumy State Pedagogical University named after A. S. Makarenko, 40002, Sumy, Str. Romenska, 87, tel.: +38 (095) 167 5952, e-mail: omvitaliy@gmail.com

$$
\text { ORCID: 0000-0003-0713-1444 }
$$

Омельяненко Віталій Анатолійович, кандидат економічних наук, старший викладач кафедри бізнес-економіки та адміністрування, Сумський державний педагогічний університет імені А. С. Макаренка, 40002, м. Суми, вул. Роменська, 87, тел.: +38 (095) 167 5952, e-mail: omvitaliy@gmail.com

ORCID: 0000-0003-0713-1444

Омельяненко Виталий Анатольевич, кандидат экономических наук, старший преподаватель кафедры бизнес-экономики и администрирования, Сумской государственный педагогический университет имени A. С. Макаренко, 40002, г. Сумы, ул. Роменская, 87, тел.: +38 (095) 167 5952, e-таil: omvitaliy@gmail.com

\title{
ARCHETYPICAL ANALYSIS OF THE INNOVATION DEVELOPMENT RESOURCES OF EUROPEAN PUBLIC ADMINISTRATIVE SPACE (COMPARATIVE APPROACH)
}

Abstract. The actualization of innovation problems in the field of public administration is explained by the fact that in recent years improving of its effectiveness, improving the quality of public functions implementation and public services providing are priority tasks in the public administration reforming process. A consequence of this is a number of significant changes that affect not only the organizational structure of the public sector, but also the principles of organization, functioning of public management space and the evaluation of public administration effectiveness.

It is shown that comparative analysis provides an opportunity to analyze the mechanisms that are implemented by developed countries and implement their organic implementation in the existing institutional matrix of Ukraine, which is based on a unique set of archetypes. It is proved that it is also necessary to identify 
innovations that directly influence the development of new solutions (innovation for innovation). This requires accumulated knowledge of innovation, which provides a comparative approach, as well as some favorable environment for their distribution, the analysis of which becomes possible due to the archetypal methodology.

According to the certain types of innovations, innovation development resources are proposed to be considered as potential opportunities (reserve capabilities, means of development, source) of certain qualities that are not yet developed. Then we can proceed to study of evolutionary factors of development: innovative processes and systems are specific and develop under the influence of national features of economic and socio-political, as well as historical development of the country.

In the study it is justified that the basis for the formation and use of innovation development resources should be the identification of the directions of the innovation process, taking into account national needs, the trends of innovation development and basic technologies of the technological structure, they have projections for public administration, as well as ensuring the expanded reproduction of innovative resources based on nonlinear models of the innovation process.

Keywords: innovation resources, public management, strategy, development, efficiency, comparative analysis, archetype.

\section{АРХЕТИПНИЙ АНАЛІЗ РЕСУРСІВ ІННОВАЦІЙНОГО РОЗВИТКУ ЄВРОПЕЙСЬКОГО ПУБЛІЧНОГО УПРАВЛІНСЬКОГО ПРОСТОРУ (КОМПАРАТИВНИЙ ПІДХІД)"}

Анотація. Актуалізація інноваційної проблематики у сфері публічного управління пояснюється тим, що останніми роками підвищення його ефективності, поліпшення якості реалізації державних функцій та надання публічних послуг є пріоритетними завданнями в процесі реформування публічного управління. Наслідком цього є низка суттєвих змін в організаційних структурах і чисельності державного апарату, а також у принципах організації, функціонування публічного управлінського простору та оцінювання ефективності публічного управління.

У дослідженні показано, що компаративний аналіз забезпечує можливість проаналізувати механізми, що реалізуються розвиненими країнами, та здійснити їх органічну імплементацію в існуючу інституційну матрицю України, що грунтується на унікальній сукупності архетипів. Доведено, що необхідні інновації, які прямо впливали б на вироблення нових рішень (інновації для інновацій). Для цього потрібні накопичені обсяги знань щодо інновацій, які забезпечує компаративний підхід, а також деяке сприятливе середовище для їх поширення, аналіз якого стає можливим завдяки архетипній методології.

\footnotetext{
Робота виконувалася за рахунок бюджетних коштів МОН України, наданих на виконання науково-дослідного проекту № 0117U003855 "Інституційно-технологічне проектування інноваційних мереж для системного забезпечення національної безпеки України” (Наказ МОН України від 10 жовтня 2017 р. № 1366).
} 
Відповідно до визначених видів інновацій ресурси інноваційного розвитку запропоновано розглядати як потенційні можливості (резервні можливості, засоби розвитку, джерела) певних якостей, які ще не розвинулись. Звідси можемо перейти до вивчення еволюційних факторів розвитку: інноваційні процеси та системи мають специфічний характер і розвиваються під впливом національних особливостей економічного, соціально-політичного, а також історичного розвитку країни.

У дослідженні обгрунтовано, що в основі формування та використання ресурсів інноваційного розвитку мають визначатися напрями інноваційного процесу з урахуванням національних потреб, тенденцій інноваційного розвитку та базових технологій технологічного укладу в їх проекції на сферу публічного управління, а також забезпечення розширеного відтворення інноваційних ресурсів на базі нелінійних моделей інноваційного процесу.

Ключові слова: інноваційні ресурси, публічне управління, стратегія, розвиток, ефективність, компаративний аналіз, архетип.

\section{АРХЕТИПНИЙ АНАЛИЗ РЕСУРСОВ ИННОВАЦИОННОГО РАЗВИТИЯ ЕВРОПЕЙСКОГО ПУБЛИЧНОГО УПРАВЛЕНЧЕСКОГО ПРОСТРАНСТВА (КОМПАРАТИВНЫЙ ПОДХОД)}

Аннотация. Актуализация инновационной проблематики в сфере публичного управления объясняется тем, что в последние годы повышение его эффективности, улучшение качества реализации государственных функций и предоставление публичных услуг являются приоритетными задачами в процессе реформирования публичного управления. Следствием этого является ряд значительных изменений, которые сказываются не только на организационной структуре и численности государственного аппарата, но и на принципах организации, функционировании публичного управленческого пространства и оценки эффективности публичного управления.

В исследовании показано, что компаративный анализ обеспечивает возможность проанализировать механизмы, которые реализуются развитыми странами, и осуществить их органическую имплементацию в существующую институционную матрицу Украины, которая базируется на уникальной совокупности архетипов. Доказано, что необходимы инновации, которые прямо влияли бы на выработку новых решений (инновации для инноваций). Для этого нужны накопленные объемы знаний относительно инноваций, которые обеспечивают компаративный подход, а также некоторая благоприятная среда для их распространения, анализ которого становится возможным благодаря архетипной методологии.

Согласно определенным видам инноваций ресурсы инновационного развития предложено рассматривать как потенциальные возможности (резервные возможности, средства развития, источника) определенных качеств, которые еще не развиты. Затем можем перейти к изучению эволюционных факторов развития: инновационные процессы и системы носят специфи- 
ческий характер и развиваются под влиянием национальных особенностей экономического, социально-политического, а также исторического развития страны.

В исследовании обосновано, что в основе формирования и использования ресурсов инновационного развития должны быть определены направления инновационного процесса с учетом национальных нужд, тенденций инновационного развития и базовых технологий технологического уклада в их проекции на сферу публичного управления, а также обеспечено расширенное воспроизведение инновационных ресурсов на базе нелинейных моделей инновационного процесса.

Ключевые слова: инновационные ресурсы, публичное управление, стратегия, развитие, эффективность, компаративный анализ, архетип.

Thesis statement. The actualization of innovation problems of the public administrative space is explained by the fact that in recent years an increase in its efficiency, improvement of the quality of implementation of state functions and provision of public services are priorities in the process of reforming public administration. Because of this, there is a number of significant changes in the organizational structure of the state apparatus, as well as in the principles of organization and functioning of public administrative space and the evaluation of the effectiveness of public administration.

Also, in recent years, the citizens of Ukraine have sought to broaden their participation in governance, which creates the public demand for the development and introduction of innovations in the field of public administration through the usage of state-of-the-art information and management technologies. It is also worth taking into account the factor of the innovative potential of society. In particular, according to monitoring studies of the Ukrainian School of Archetypic, ap- proximately 10 million Ukrainians have an innovative potential, and in the near future, this figure may reach its limit of 16 million. This raises the question of developing strategies that will allow the usage of this resource in the public administrative space as well.

Thus, the analysis of resources of innovation development as one of the key factors that ensure the effectiveness of the field of public administration necessitates a comprehensive analysis of the processes taking place in this field, the study of new, previously unexplored phenomena and problems concerning the provision of these resources. Therefore, the creation of a full-fledged analytical support for the effective decisions making in the field of public administration is an urgent problem, the solution of which is capable of ensuring the country's effective development.

Given the weak development of this issue and the practical lack of methodologies for assessing the effectiveness of using innovations in the field of public administration in the presence of an ever-increasing need for such resour- 
ces, the topic of research is particularly relevant.

Analysis of recent research and publications. The most important modern theory that links resources and development is the competitiveness resource concept, based on the studies of B. Wernerfelt, R. M. Grant, K. Prahalad, G. B. Kleiner, and others. We note that these approaches are based on economic development. Within the limits of economic research, the resource concept implies the presence of dependency of a state of the entity in the market on its available resources, the effectiveness of which is determined by its organizational capabilities.

We believe that such an approach can apply to public administration with certain adjustments. However, in our opinion, there are certain peculiarities in the process of innovation development of public administration field, related to the differentiation of processes in state bodies and commercial organizations and the corresponding criteria for evaluating their activity (efficiency). The presence of these features requires the development of appropriate approaches to the analysis of problems in the management of innovation development of public administration and the identification of appropriate development resources.

Analysing the issues of development resources, we should note that in European countries much attention is paid to solving the problems of the relation between the quality and efficiency of management in terms of costs [17]. Defining the essence of the concept of New Public Management, D. Osbome and T. Gaebler focus on the efficiency and effectiveness of the public admi- nistration process in all its forms economic, social and organizational [5], while considering resources (primarily human capital) and innovations that allow maximizing the effects of their usage [4].

In the study "Public Administration in Ukraine: Relations with Archetypes and Development Priorities" [9], a number of priorities for the development of public administration were identified, of which the main, in our opinion, is the accumulation of socalled synthesized capital (a combination of human, intellectual and social capital ) with its subsequent implementation at the national level, taking into account archetypes, and creating conditions for the transformation of this capital into a national geo-economic capital, ensuring the effectiveness of the innovative model of development of the state. It should be noted that the priorities mentioned by the authors almost do not consider the innovative aspect and the corresponding features of the public administrative space.

In the research conducted by E. A. Afonin, L. V. Goniukova and R. V. Voitovych [10], the aspects of new forms of active influence of society on state and administrative processes are considered through the innovative forms of partnership and cooperation within the new context of social values initiated by the postmodern type of social development.

Analysing the broader context of the effectiveness of public administration, the authors of the research work "The National Security of Ukraine" [18] state that interdisciplinarity of national security study based on the effectiveness of public administration pri- 
marily manifests itself in the research of complex national security issues that need to be analysed and solved involving the methodology of numerous separate scientific directions.

In various studies [2; 21-23], the issue of evaluating the effectiveness of public administration based on values [22] and set of effects [21], in particular on the example of the European public space and through the introduction of innovations [2; 23].

Formulating a range of possible factors and analytical approaches, let us turn to classical theses on institutional changes. They note that institutional boundaries create incentives for investing in knowledge, and incentives determine individuals' choice of knowledge and skills that give them the maximum benefit. In addition, a number of institutionalist scholars emphasize that the understanding of the world (accordingly, with subsequent actions of an innovative nature) is conditioned by the mental models of individuals.

As a result, we come to the task of an additional conceptualization of the resources of innovation development of the public administration field, as well as the formation of analytical foundations for their management.

The objective of the study is to archetypically analyse the strategic aspects of the formation of innovation development resources based on the usage of a comparative approach to European public administrative space.

Methodology of research. General research methods of analysis and synthesis, historical and logical, system and structural and functional analysis will be used to solve the research tasks. Among the innovative methods for de- signing an innovation strategy, simulation institutional and evolutionary modeling to maximize synergy effects in the public administrative space and a systematic approach to its formation will be used.

To solve a wide range of optimization tasks, adapted decision-making methods based on optimization of performance indicators, methods for finding innovative ways of development, methods of comprehensive analysis of policy development and methods of project management will be used.

At the same time, the necessity of usage of archetype methodology is due to the fact that the tasks of a comprehensive reform of public administration should be decided taking into account national features of each country. The approval of the appropriateness of this approach is found in José Caballero, Senior Economist at the Competitiveness Centre of IMD World Competitiveness Center Business School, who emphasizes the role of national peculiarities for choosing development priorities and strategies for their practical implementation, and also notes the special importance of the EU as an opportunity for Ukraine, since here it is about compliance with norms concerning democracy, anti-corruption, transparency of government actions and system effectiveness of public administration [11].

The above thesis confirms the relevance of our research, because in this context, comparative analysis provides an opportunity to analyse the mechanisms implemented by developed countries and to implement them organically in the existing institutional matrix of Ukraine, based on a unique 
set of archetypes. It is also necessary to identify innovations that would have a direct impact on the development of new solutions (innovation for innovation). This requires accumulated knowledge on innovative practices provided by a comparative approach, as well as a favourable environment for their distribution, analysis of which becomes possible due to archetypical methodology.

Results. The research is based on such ideas, which allow to combine the theory of public administration, innovation development and archetypical basis of management processes and to carry out a comparative analysis.

First, in the case of public administration, the concept of developmental resources should be clarified, and it implies that in contrast to existing, these resources should be considered not only as a factor, which leads to higher results of separate entities, but also as a factor for development the state system (in particular, the economy) as a whole. In general, innovative resources cover a range of resources that provide the innovation process (logistical, financial, human, organizational and managerial, and information ones).

On the basis of this, management of the innovation development of the field of public administration can be analysed as a targeted effect on the system, "designed to adjust the natural motion, determined by the initial conditions, the energy state and the processes of exchange of the system with the environment" [13, p. 26] in order to adapt the system to new conditions. In the study "Management of Innovation and Innovation in Management" [15], the following types of innovations and related processes in the field of public administration are distinguished:

- innovation for institutions where focus is on restoring existing institutions and/or creating new organizational structures;

- organizational innovation, which involves the implementation of new procedures (management methods) in the field of public administration;

- innovation in the form of process improvement, with an emphasis on improving the quality of public services;

- conceptual innovation aimed at implementing new forms of governance (interactive policy formation, public administration based on broad participation of society, horizontal/network administration).

The next aspect is based on the fact that, according to these types of innovations, development resources should be considered as potential opportunities (reserve opportunities, means of development, sources) of certain qualities that have not yet developed (not functioning, not used). From this point, we can proceed to the study of evolutionary factors of development: innovative processes and systems are specific in nature and develop under the influence of national peculiarities of economic, socio-political, and historical development of the country. Accordingly, systemic innovations in public administration have profound consequences both for the individual and for a number of groups (social and professional groups) and therefore cannot be implemented (be effective) without adequate psychological analytics, which assists to individuals and groups in the process of innovation and adaptation to changes. 
Another factor is based on the fact that the problems of the development of innovative potential (and related resources) and the implementation of innovations in the field of public administration are associated with human and organizational factors, as well as the personal orientation of state officials. Innovation activity is a sequence of complex and multi-stage processes implemented by different groups, dynamic interaction of individuals, social groups, departments and organizations. At the same time, the success of change is always associated with the overcoming of a number of barriers and resistance, therefore innovation is impossible without significant efforts, taking into account managerial, organizational and social factors [19]. Consequently, the resources of innovation development can be considered in the context of elimination of these obstacles.

An important aspect is connected with the fact that the system of public administration consists of two subsystems: the controlling (managerial entity) and managed (object of management - branch, spectrum of relations and functions, project, etc.) subsystems. Accordingly, we propose to consider the sources of the formation of innovation development resources in each of these systems as well, but taking into account their systemic unity.

The European Institute of Innovation and Technology puts the business, knowledge and education at the corners of the "knowledge triangle", and the state and society "surround" this triangle by shaping the development environment. Business and education are the most attractive for cooperation, and it is most difficult to create a communication process with the state.

In accordance with the hierarchical approach, within the framework of the analysis of the evolution of systems, one distinguishes three main models of the introduction of novelties in the activities of public structures [25]:

- "top-down" or "policy-dependent" - innovative activity in the functioning of lower structures does not arise without direct indication from hierarchically higher organs.

- "bottom-up" - government bodies within their authority monitor innovation in the various sectors of the economy and the social sphere, encourage innovative initiatives of employees, analyse practical experience and transform it into the best practices and methods suitable for distribution.

- "knowledge-scanning" - organizations "scan" the existing experience of introducing innovations in such spheres of management and, based on its results, make decisions to improve their own managerial technologies.

In the world practice, the development of innovations is traditionally carried out in accordance with two basic strategies, on the basis of which we have developed a scheme for the creation of resources for innovative development of the public administrative space (see Figure).

Innovations can only exist in the environment prepared for them. However, if you try to manage innovation without introducing changes to the upper levels (or vice versa), the innovation potential will not be used. Therefore, it is from the combination of public potential and the actions of the authorities at a certain level (coun- 


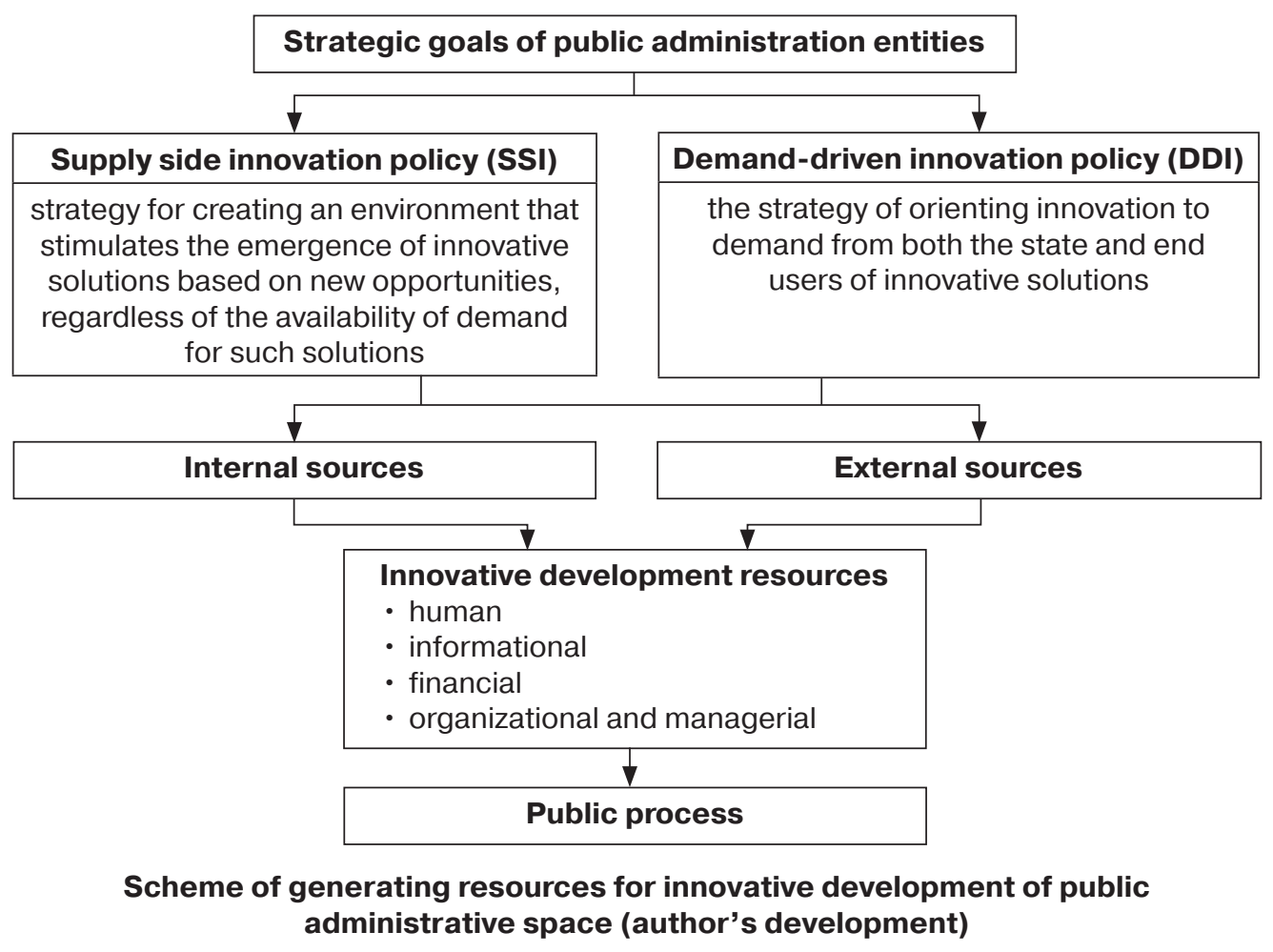

try, region, economic entity) the effectiveness of the actions of subordinates (subsystems, controlled systems, objects, or processes) depends largely.

In this context, public administration can be seen as a process of finding the best (innovative) ways to use public resources in order to achieve the priority goals of social development, jointly implemented by the government, representative bodies and civil society. Therefore, all democratic forms of governance (namely, the transparency and participativeness inherent to democracy) contribute to the realization of the potential of "social creativity" and the formation through an understanding of more adequate and acceptable conditions of existence, acting as a "social experiment" and a way of implementing social innovation.
For analytics of innovations in the system of public space, we suggest to use the provisions of the systemic approach, in particular, the transparency of the system. An archetypical component in this context is important, since social communications based on them allow changing the ways of interaction with society, timely responding to and anticipating external challenges [14]. On the other hand, the flexibility of the system as its ability to structural adaptation in response to environmental influences is relevant. In this aspect, the transparency of the public administration system is a reflection of its state for interested agents and determines the readiness for so-called state and public administration.

Any evolving system has resources that are significantly larger than necessary for its functions (the property of 
redundancy of the system). This aspect can also be explained by the definition of public administration that involves active interaction. A system that evolves from its own resources is self-evolving. This type of system has the most innovative potential. We propose to consider this aspect, based on the fact that the fundamental resource of knowledge is formed, accumulated and reproduced through another fundamental resource of modern innovative development human capital (a set of skills, qualifications, competencies and motivations for their realization). Accordingly, in the context of motivations, one can also consider the nature of the influence of archetypes.

The transparency of the public administration system can be defined as the ability to identify and take into account changes in the external environment for the sake of its own development. Each point of the transparent system can be considered as a separate "organism", capable of self-development. Using the external environment in diachrony, involving new types of perception and transforming the structure of conceptinterpreters, the content system itself reproduces and develops its conceptual structure. Thus, transparency creates conditions for self-organization.

The Western model of analytical public administration is based on innovative dialogue formats that widely involves both public administration institutions and a number of collaborative partners and society as a whole. An important aspect of this model in terms of attracting development resources is also the ability to compete with the private sector in the labour market for limited quality human resources.
The practice of using crowdsourcing in the field of public administration is widespread through specially designed actions to increase awareness as to decision-making and policy and involvement in public sector work (participation). In particular, in European countries, citizens can indicate their location on the map, write about the problem, offense or express their opinion concerning a certain decision. The practice of consultative referenda and public discussions should also be noted.

In this context, it's worth mentioning the concept of Hernando de Soto [24], which develops the views of the Austrian economic school representatives based on the role of entrepreneurial talent in ensuring dynamic (adaptive) efficiency. According to the researcher, the dynamic effectiveness of the institute (system) depends on the level of their creative ability to entrepreneurship and, which is especially important for our study, coordination (internal and external).

A vivid example of the practical implementation of this concept is the innovative system in France, where at the expense of the state budget funds are funded up to $80 \%$ of the cost of fundamental research (relatively high level in the EU), and the high degree of direct state regulation in the field of science is balanced by the emphasis on the collectivist (public) approach to determine the strategic priorities of scientific and technological development [25]. It should be noted that this work involves not only scientists and employees of higher education, but also all interested parties representing the interests of the state, society and busi- 
ness. This is a vivid example of crowdsourcing for finding ideas, maintaining systemic feedback and quality control.

These examples show that with the help of network communications of crowdsourcing one can effectively solve problems of any complexity involving the innovative resources of stakeholders - from branding of the territory, planning development to optimizing the processes of providing public services.

Despite the complexity of the process, the collectivist method of choosing and agreeing priorities and solutions can aggregate external challenges and relevant societal demands based on actual archetypes, along with the corresponding innovative potential, and therefore can effectively play the role of the instrument of legitimizing decisions of the authorities.

In the continuation of the topic of transparency, let us focus on the socalled interaction resources. Accordingly, two interrelated logics of network interaction in the public administrative space can be distinguished: external formal and organizational (organization of public administration through cooperation and association of social resources) and internal - subjective (logic of interpersonal relations, selfdetermination and self-realization in networks). In these networks, the participants are closely linked to the common goal, but at the same time, they take into account the interests of each one. The links in the interaction are horizontal in nature, which involves autonomy, equality and transparency of the network entities and eliminates the imposed instructions from above.
A comparative analysis also revealed that the concept of total quality management (TQM) is explicitly or implicitly is used when introducing innovations in the European public space. According to TQM, innovation management covers all strategic and operational tasks of organizing, planning, coordinating and controlling public administration processes. Consequently, there is an opportunity to identify innovative resources in certain processes of public administration, and in the case of an archetypal approach, to combine them with the motives of the activity of all stakeholders.

On the basis of the possibility of counteracting archetypes that counteract innovation, it is necessary to identify appropriate managerial innovations. This factor is also taken into account in modern concepts of public administration. In particular, one of New Public Management (NPM) experts, R. Behn defines NPM as "a collection of tactics and strategies aimed at overcoming inefficiencies inherent in the traditional public sector model" [1].

The usage of elements of the economic approach and social communications, capable of providing external resources, forms an effective methodological basis for analysing the resources of innovation development. Therefore, in order to form the strategic principles for reforming the public administrative space in Ukraine, it is expedient to use D. Kettl's approach, which offers six main characteristics of NPM such as productivity, marketization, customer orientation, decentralization, target orientation and reporting on results [3, p. 30-33].

In the framework of the implementation of these characteristics, let us 
note that the form of stabilizing the trajectory of institutional dynamics are social contracts between the society and the state. In this case, according to Charles Prather [20], trust is a decisive factor in the development of innovation.

In the case of Ukraine, conducted at the end of 2017 by the Ilko Kucheriv Democratic Initiatives Foundation and the Razumkov Centre, a nationwide survey shows a further increase in distrust in state structures compared to 2016. According to the indicators of trust in the authorities, Ukraine, according to a number of Ukrainian and European social studies, is steadily the last among the EU countries. The illegitimacy of basic formal institutions for most of society and the lack of democratic mechanisms for controlling the authorities intensify the archetypes of individualism, which leads to the loss of cooperative resources.

The formation of innovation development resources should also be considered in terms of the value of public administration services, which is closely linked to TQM and the approach of D. Kettl and allows for the establishment of indicators similar to economic approaches.

In the opinion of UN experts, stated in the United Nation e-government Survey [8, p. 14], the next stage after e-Government should be Connected Governance, which aims to improve cooperation between government services, to deepen consultation and to engage citizens that will allow regional and international multi-stakeholder participation in the process.

Another concept of Connected Governance is associated with the idea of managing public values. This approach is the result of the transition from traditional state administration to management of interactions, and subsequently to the management of public values [7].

Thus, in the framework of the formation and usage of resources for innovation development, there should be a definition of the directions of the innovation process taking into account national needs and values, trends of innovation development and the basic technologies of the technological context in their projection into the sphere of public administration, and also ensuring the expanded reproduction of innovative resources on the basis of nonlinear models of innovation process.

Based on the analysis, we can formulate such components of management technologies that will stimulate the attraction of innovative resources:

- a project approach to the priorities of the government and the activities of public administration institutions;

- developed competences of public administration employees;

- regular review of expenditures in state budget institutions and the policy of "zero bureaucracy";

- improved performance evaluation system;

- management of network strategic communication of government priorities and reforms;

- audit of salary policy of employees.

Conclusion and prospects of further research. The research determines the methodological foundations for managing the resources of innovation development of public management space. The analysis of modern concepts 
of the public management space of the EU countries was carried out and the main mechanisms of implementation of changes in it were determined.

The usage of resources of the innovation development of the public administrative space can be carried out subject to the introduction of a new paradigm of public administration based on the adaptation of modern management approaches (targeting a citizen as a client, working in conditions of transparent competition for resources, improving the quality of public services, applying corporate ideology, motivation to self-development) taking into account national specifics.

Prospects for further research include the consideration of specific (sectoral) mechanisms of public administration.

\section{REFERENCES}

1. Kostuk I. K. (2014), "Application of innovative technologies in public administration in the context of European standards", Molodoj uchenyj, № 21, p. 519-521.

2. Osbome D. and Gaebler T. (1992), Reinventing Government. How the Entrepreneurial Spirit is Transforming the Public Sector, N. Y.

3. Kudrina O., Volodin D., and Omelyanenko V. (2017), "Conceptual principles of development resources security analysis", Marketing and Management of Innovations, № 2, p. 280-287.

4. Amosov O. and Gavkalova N. (2014), "Public Administration in Ukraine: Relationship with Archetypes and Development Priorities", Publichne upravlinnia: teorija ta praktyka, № 2 (18), p. 6-13.

5. Afonin E. A., Gonjukova L. V. and Vojtozych R. V. (2006), Gromadska uchast u tvorenni ta zdijsnenni derzhavnoi polityky [Public participation in the creation and implementation of public policy], Center for Support of Civil Service Institutional Development, Kyiv.

6. Lipkan V. A. (2009), Nacionalna bezpeka Ukrainy [National Security of Ukraine], KNT, Kyiv.

7. United Nations (2014), Good Practices and Innovations in Public Governance United Nations Public Service Awards Winners, 2012-2013, United Nations, New York.

8. Soroko V. M. (2012), Rezultatyvnist ta efektyvnist derzhavnogo upravlinnia i miscevogo samovriaduvannia [Effectiveness and Efficiency of Public Administration and Local Self-Government], NADU, Kyiv.

9. Tanhuk O. A. (2015), "The main approaches to the evaluation of the effectiveness of public administration", Visnyk Nacionalnoi akademii derzhavnogo upravlinnja pry Prezydentovi Ukrainy, № 3, p. 63-71.

10. Tjutin D. V. (2014), "Evolution of New Public Administration: The Logic of Efficiency, Efficiency and Management of Public Values", Teoryia i praktyka obshhestvennogo razvytyia, № 5, p. $179-181$.

11. Fokus.ua (2018), "Outside the competition. Jose Caballero on where to start real reforms in Ukraine", Fokus. ua, available at: https://focus.ua/ money/393501/ (Accessed 4 February 2018).

12. Dudnyk I. M. (2010), Vstup do zagalnoi teorii sistem [Introduction to the general theory of systems], Poltava.

13. Kniazev S. N. and Gancherenuk I. I. (2007), "Management of innovation and innovation in management", Universytetski naukovi zapysky, № 3, p. 41-44.

14. Naumov S. Yu. (2008). Sistema gosudarstvennogo upravleniia [The system 
of public administration], Forum, Moscow.

15. Yanyk A. A. and Popova S. M. (2015), "New trends in the state management of the development of science in France”, Gosudarstvennoe upravlenye. Elektronnyj vestnyk, № 51, p. 152184.

16. Uerta de Soto H. (2011), Socialno-ekonomicheskaia teoriia dinamicheskoj effektivnosti [Socio-economic theory of dynamic efficiency], Socium, Chelyabinsk.

17. Behn R. D. (2001), Rethinking Democratic Accountability, Washington, 2001.

18. Kettl D. (2000), The Global Public Management Revolution: A Report on the Transformation of Governance, Washington.

19. Prater Ch. "How to create innovations" available at: https://econ.wikireading. ru/75931 (Accessed 4 February 2018).

20. UN (2008), United Nations e-Government Survey. From e-Government to Connected Governance, New York: UN.

21. Stoker G. (2006), "Public Value Management. A New Narrative for Networked Governance?", American Review of Public Administration, Vol. 36, № 1.

22. Prokopenko O. and Omelyanenko $V$. (2017), "Priority Selection Within National Innovation Strategy in Global Context", Economics and Business, Vol. 30, Iss. 2, p. 5-18.

23. Donchenko E. A. (2010), "Phenomenology of the Archetype and Public Administration”, Publichnoe upravleniie: teoryia i praktyka, № 3-4, p. 35-36.

24. Ivanova N. L. (2014), "Introduction of innovations in the sphere of public administration: problems and factors", Voprosy upravleniia, [Online], № 4 (29). available at: http://vestnik.uapa. ru/ru/issue/2014/04/02/ (Accessed 4 February 2018).
25. Kozak V. I. (2015), "Formation of creativity in the system of public service of Ukraine: problems and prospects of development", Aspekty publichnogo upravlinnia, № 10, p. 39-47.

\section{СПИСОК ВИКОРИСТАНИХ ДЖЕРЕЛ}

1. Behn R. D. Rethinking Democratic Accountability / R. D. Behn. Washington, 2001.

2. Good Practices and Innovations in Public Governance United Nations Public Service Awards Winners, 2012-2013 // United Nations. - New York, 2014.

3. Kettl D. The Global Public Management Revolution: A Report on the Transformation of Governance / D. Kettl. Washington, 2000.

4. Kudrina $O$. Conceptual principles of development resources security analysis / O. Kudrina, D. Volodin, V. Omelyanenko // Marketing and Management of Innovations. 2017. - № 2. - P. 280-287.

5. Osbome D. Reinventing Government. How the Entrepreneurial Spirit is Transforming the Public Sector / D. Osbome, T. Gaebler. - N.Y., 1992.

6. Prokopenko O. Priority Selection Within National Innovation Strategy in Global Context / O. Prokopenko, V. Omelyanenko // Economics and Business. - 2017. - Vol. 30, Iss. 2. P. 5-18.

7. Stoker G. Public Value Management. A New Narrative for Networked Governance? / G. Stoker // American Review of Public Administration. 2006. - Vol. 36. - № 1.

8. United Nations e-Government Survey. From e-Government to Connected Governance. - New York : UN, 2008.

9. Амосов О. Публічне адміністрування в Україні: зв'язок з архетипами та пріоритети розвитку / О. Амосов, 
Н. Гавкалова // Публічне управління: теорія та практика. - 2014. № 2 (18). - C. 6-13.

10. Афонін E. A. Громадська участь у творенні та здійсненні державної політики / Е. А. Афонін, Л. В. Гонюкова, Р. В. Войтович. - Київ : Центр сприяння інституційному розвитку держ. служби, 2006. - 160 с.

11. Вне конкуренции. Хосе Кабальеро о том, с чего Украине начать настоящие реформы [Електронний ресурс]. - Режим доступу: https:// focus.ua/money/393501/

12. Донченко E. А. Феноменология архетипа и государственное управление / Е. А. Донченко // Публичное управление: теория и практика. 2010. - № 3-4. - С. 35-36.

13. Дудник I. М. Вступ до загальної теоpiї систем / I. М. Дудник. - Полтава, 2010. - 129 c.

14. Иванова Н. Л. Внедрение инноваций в сфере государственного управления: проблемы и факторы [Електронний ресурс] / Н. Л. Иванова // Вопр. управления. - 2014. - № 4 (29). - Режим доступу: http://vestnik.uapa.ru/ru/issue/2014/04/02/

15. Князев С. Н. Управление инновациями и инновации в управлении / С. Н. Князев, И. И. Ганчеренок // Університетські наук. зап. - 2007. № 3. - C. 41-44.

16. Козак B. I. Формування креативності в системі публічної служби України: проблеми та перспективи розвитку / В. І. Козак // Аспекти публічного управління. - 2015. № 10. - С. 39-47.

17. Костюк И. К. Применение инновационных технологий в государ- ственном управлении в контексте европейских стандартов / И. К. Костюк / / Молодой ученый. - 2014. № 21. - С. 519-521.

18. Ліпкан B. А. Національна безпека України / В. А. Ліпкан. - Київ : KHT, 2009. - 575 c.

19. Наумов С. Ю. Система государственного управления / С. Ю. Наумов. М. : Форум, 2008. - 304 с.

20. Пратер Ч. Как создавать инновации [Електронний ресурс] / Ч. Пратер. - Режим доступу: https://econ. wikireading.ru/75931

21. Сороко B. M. Результативність та ефективність державного управління і місцевого самоврядування / В. М. Сороко. - К.: НАДУ, 2012. $260 \mathrm{c}$.

22. Таньчук О. А. Основні підходи до оцінювання ефективності публічного управління / О. А. Таньчук // Вісн. Нац. академії держ. управління при Президентові України. 2015. - № 3. - С. 63-71.

23. Тютин Д. В. Эволюция нового государственного управления: логика эффективности, результативности и менеджмента публичных ценностей / Д. В. Тютин // Теория и практика общественного развития. 2014. - № 5. - C. 179-181.

24. Уэрта де Cото X. Социально-экономическая теория динамической эффективности / Х. Уэрта де Сото. Челябинск : Социум, 2011.

25. Яник A. A. Новые тренды в государственном управлении развитием науки во Франции / А. А. Яник, C. М. Попова // Государственное управление. Электронный вестн. 2015. - № 51. - С. 152-184. 